net clinics. He co-managed the placements of the students and monitored their experiences with the community organizations.

After residency, Karl envisions his future career in an integrated practice that offers a variety of services in both conventional and complementary medicine as well as small groups, social/community support, psychiatry, counseling, exercise, and nutrition. He also plans to volunteer for the underserved both nationally and internationally.

Jane Ireland

Pisacano Leadership Foundation

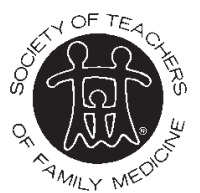

From the Society of Teachers of Family Medicine

Ann Fam Med 2009;7:565-566. doi:10.1370/afm.1066.

\section{THE STFM SPECIAL TASK FORCE ON THE FUTURE OF FAMILY MEDICINE: BUILDING THE FOUNDATION FOR THE MEDICAL HOME}

In 2005 the STFM Board formed a special task force to respond to the future of family medicine (FFM) ${ }^{1}$ report's strategic initiative 8 , recruiting and training a diverse workforce. The task force set priorities in 4 areas: designing a competency based curriculum for the new model of family medicine (FM); supporting initiatives for international medical graduates (IMGs) in FM residencies, enhancing pipeline recruitment of medical students likely to enter FM; and, developing leaders in FM. This article summarizes the task force's accomplishments in the 4 focus areas and suggests directions for the future.

\section{Competency-Based Curriculum for the New Model (Patient-Centered Medical Home)}

The competency-based curriculum (CBC) for the new model (patient-centered medical home or PCMH) is designed to offer a continuum of teaching and learning resources for predoctoral, residency, and preceptor/ teacher education in 4 important areas:

- group visits, led by Julie Schirmer (http://www. fmdrl.org/1415)

- advanced access, led by George Valko (http:// www.fmdrl.org/1418)

- quality improvement, led by Peter Carek and Bill Shore (http://www.fmdrl.org/1417)

- the chronic care model, led by Jeff Susman (http://www.fmdrl.org/1416)
Each unit contains model goals, objectives, evaluation materials, checklists, teaching activities, and faculty development suggestions.

Recent efforts, such as the collaboration between the Association of Departments of Family Medicine (ADFM) Clinical Group and the University of Minnesota, have resulted in a clearinghouse for pay for performance (P4P) developed by David Satin, MD (http://www.student.med.umn.edu/p4p/index.php) and the establishment of the STFM Group on the PCMH (chaired by John Rogers and Caryl Heaton), and resources for the PCMH (http://www.stfm.org/initiatives/future.cfm).

\section{Initiatives for International Medical Graduates} in Family Medicine Residencies

Recognizing that international medical graduates (IMGs) comprise a significant and increasing (approximately $40 \%$ ) percentage of the family medicine workforce, STFM assessed these IMG's needs through a survey (Simpson et al, forthcoming) and developed a related series of training workshops for entering residents and teaching resources. While the initial workshop format was successful, the number of participants was insufficient to sustain this approach. Instead, alternative resources to support IMGs have been developed, including instructional materials that program directors and faculty can use to educate their residents (eg, http://www.fmdrl.org/index.cfm?event=c. beginBrowseD\&clearSelections $=1 \&$ criteria $=i m g \# 1613$ ) The STFM IMG Initiative will be producing webbased materials for programs beginning in late 2009 .

\section{Family Medicine Pipeline Project}

The Family Medicine Pipeline Project (led by Janice Benson, Ellen Whiting, and David Pole) focused on the recruitment of a diverse workforce into family medicine (http://www.stfm.org/initiatives/pipeline. cfm). FutureFamilyDocs' innovative web site provides valuable resources (eg, posters, talking points) that we can use to recruit high school students to family medicine (http://www.futurefamilydocs.org/). Other key accomplishments include the formation of an STFM Group on Family Medicine Pipeline, which first met at the 2009 Annual Conference and the development of resources on patient confidentiality, privacy and HIPAA rules for shadowing students. Additional activities include a national contest for clinicians to submit photos of themselves or colleagues talking with young patients and a collaboration with the National Area Health Education Consortium Organization (NAO).

\section{Leadership Development}

The leadership workgroup, led by Terry Steyer (current STFM president), identified critical resources and 
gaps within the discipline by initially summarizing existing leadership development programs: (http:// www.stfm.org/leadership/leadershipuser.html). This group also prepared a leadership survey which identified the greatest areas of need including financial management, grant writing, budgeting, working with the media, publishing, and advocacy skills. STFM was deemed as a key source of leadership training and will focus on "emerging leaders" in STFM groups and committees and leadership opportunities at STFM meetings. Care is being exercised to coordinate with other excellent leadership programs in the discipline.

\section{Summary}

With limited funding, the STFM special task force on the future of family medicine has made substantive progress in addressing 4 focused areas of need within the discipline and built a strong foundation for the patient centered medical home of the future. Please use the resources our Society's members have developed to enhance the future of our specialty.

Jeff Susman, MD, Jim Tysinger, PbD on bebalf of the STFM Special Task Force on the Future of Family Medicine Bill Mygdal, EdD (Chair), Jobn Rogers, MD (Co(hair), Janice Benson, MDi Angela Broderick, CAE; Stacy Brungardt, CAE; Caryl Heaton, DO, Charles Mouton, MD, Terry Steyer, MD, Ellen Whiting, MEd, Deborab Witt, MD, Katby Zoppi, PbD, MPH

\section{References}

1. Martin JC, Avant RF, Bowman MA. The future of family medicine: a collaborative project of the family medicine community. Ann Fam Med. 2004;2(Suppl 1):S3-S32.

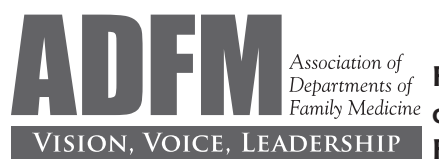

From the Association of Departments of Family Medicine

Ann Fam Med 2009;7:566-567. doi:10.1370/afm.1064.

\section{OUT OF THE IVORY TOWER: ENGAGING THE NATIONAL DIALOGUE ON THE PATIENT-CENTERED MEDICAL HOME}

Popular myth holds that medical school department chairs sit in ivory (or ivy) towers, far from the din of humanity, health, and illness. Nothing could be further from the reality for the vast majority of family medicine chairs and faculty. Although research, education, and scholarly work hold high esteem, there is clear and ever-growing engagement among chairs of family medicine in important clinical areas including opera- tions, patient care, community service, and transformation of practices to meet the needs of our patients and our discipline.

Annual survey data in 2007 documented that two-thirds (68\%) of Chairs of Departments of Family Medicine spend $10 \%-30 \%$ time on clinical care, and in 2008, survey data revealed that same proportion are directly involved in major clinical operations in their own institutions. Chairs are actively training the family physicians of the future. Our 2008 survey data reveal more than two-thirds (78\%) of chairs have clerkship students work with them in clinic, and $86 \%$ of chairs precept residents in family medicine centers. Since establishing a standing Clinical Committee in 2004, ADFM has increased its clinical focus through advocacy, advancing implementation of electronic health records in departments, and publications concerning clinical innovations in academic health centers ${ }^{1,2}$ and advanced access in academic settings., ${ }^{3,4}$ Clinical content at the annual ADFM winter meetings has increased substantially since 2005, culminating in 2009 with a full-day theme session concerning the PatientCentered Medical Home (PCMH) and the PatientCentered Primary Care Collaborative (PCPCC). Paul Grundy, MD, president of the PCPCC, attended the 3-day conference and actively engaged with ADFM members driving practice transformation.

A critical outcome of the 2009 ADFM winter meeting was the strategic decision to become more directly involved with the PCPCC. Immediately following from the winter meeting, we took advantage of the PCPCC's many teleconference opportunities to learn more and to engage our leadership and members. In May, ADFM was invited to be a member of the PCPCC Advisory Committee which has opened up additional direct avenues for this engagement, such as being invited to participate on their newly formed Legislative committee. Given the growing importance of this movement, we asked Kevin Grumbach and Mary Hall (Vice-Chairs of the ADFM Legislative Affairs Committee) to participate in this committee as our liaisons and they have taken active roles.

The PCPCC continues to expand in its scope of activity, while remaining focused on fomenting the adoption of its agenda (http://www.pcpcc.net). Many of us are increasingly impressed by its energetic partnership of employers, health insurance, healthcare, practitioners, consumer groups and academics. As a member of the Advisory Committee, ADFM participates with the PCPCC Executive Committee in many of the core activities. As ADFM President, Jeffrey Borkan attended the September 1, 2009, Strategic Planning Meeting (about 30 attendees, including an AAFP representative and Al Talia, representing the Robert 